\title{
Influence of isoflurane on the diastolic pressure-flow relationship and critical occlusion pressure during Arterial CABG Surgery: A randomized controlled trial
}

José Hinz, Ashham Mansur, Gerd G Hanekop, Andreas Weyland, Aron F Popov, Jan D Schmitto, Frank FG Grüne, Martin Bauer, Stephan Kazmaier

The effects of isoflurane on the determinants of blood flow during coronary artery bypass graft (CABG) surgery are not completely understood. This study characterized the influence of isoflurane on the diastolic pressure-flow (P-F) relationship and critical occlusion pressure (COP) during CABG surgery. Twenty patients undergoing CABG surgery were studied. Patients were assigned to an isoflurane or control group. Hemodynamic and flow measurements during CABG surgery were performed twice ( 15 minutes after the discontinuation of extracorporeal circulation (T15) and again 15 minutes later (T30)). The zero flow pressure intercept (a measure of COP) was extrapolated from a linear regression analysis of the instantaneous diastolic P-F relationship. In the isoflurane group, the application of isoflurane significantly increased the slope of the diastolic P-F relationship by $215 \%$ indicating a mean reduction of coronary vascular resistance (CVR) by $46 \%$.

Simultaneously, the mean diastolic aortic pressure (MDAP) decreased by $19 \%$ mainly due to a decrease in the systemic vascular resistance index by $21 \%$. The COP, cardiac index, heart rate, left ventricular end-diastolic pressure (LVEDP) and coronary sinus pressure (CSP) did not change significantly. In the control group, the parameters remained unchanged. In both groups, COP significantly exceeded the CSP and LVEDP at both time points. We conclude that short-term application of isoflurane at a sedative concentration markedly increases the slope of the instantaneous diastolic P-F relationship during CABG surgery implying a distinct decrease with CVR in patients undergoing CABG surgery. 
1 Influence of Isoflurane on the Diastolic Pressure-Flow Relationship and Critical

2 Occlusion Pressure during Arterial CABG Surgery: A randomized controlled trial

4 Jose Hinz ${ }^{1}$, Ashham Mansur*1, Gerd Gunnar Hanekop ${ }^{1}$, Andreas Weyland ${ }^{2}$, Aron Frederik

5 Popov $^{3}$, Jan Dieter Schmitto ${ }^{4}$, Frank Grüne ${ }^{5}$, Martin Bauer ${ }^{1,}$ Stephan Kazmaier ${ }^{1}$

$8{ }^{1}$ Department of Anesthesiology, University Medical Center Goettingen, Georg-August-

9 University Goettingen, D-37075 Goettingen, Germany

10 2Department of Anesthesiology and Intensive Care Medicine, Medical Center Oldenburg,

11 Germany

$12{ }^{3}$ Department of Cardiothoracic Transplantation \& Mechanical Support, Royal Brompton \& Harefield Hospital, London, United Kingdom

${ }^{4}$ Department of Cardiothoracic, Transplant and Vascular Surgery, Hannover Medical School, Hannover, Germany

${ }^{5}$ Department of Anesthesiology, Erasmus MC, Rotterdam, the Netherlands 
31

$32 *^{*}$ Corresponding author:

33 E-mail: ashham.mansur@med.uni-goettingen.de

\section{Abstract}

The effects of isoflurane on the determinants of blood flow during coronary artery bypass graft (CABG) surgery are not completely understood. This study characterized the influence of isoflurane on the diastolic pressure-flow (P-F) relationship and critical occlusion pressure (COP) during CABG surgery. Twenty patients undergoing CABG surgery were studied. Patients were assigned to an isoflurane or control group. Hemodynamic and flow measurements during CABG surgery were performed twice (15 minutes after the discontinuation of extracorporeal circulation (T15) and again 15 minutes later (T30)). The zero flow pressure intercept (a measure of COP) was extrapolated from a linear regression analysis of the instantaneous diastolic P-F relationship. In the isoflurane group, the application of isoflurane significantly increased the slope of the diastolic P-F relationship by $215 \%$ indicating a mean reduction of coronary vascular resistance (CVR) by 46\%. Simultaneously, the mean diastolic aortic pressure (MDAP) decreased by 19\% mainly due to a decrease in the systemic vascular resistance index by $21 \%$. The COP, cardiac index, heart rate, left ventricular end-diastolic pressure (LVEDP) and coronary sinus pressure (CSP) did not change significantly. In the control group, the parameters remained unchanged. In both groups, COP significantly exceeded the CSP and LVEDP at both time points. We conclude that short-term application of isoflurane at a sedative concentration markedly increases the slope of the instantaneous diastolic P-F relationship during CABG surgery implying a distinct decrease with CVR in patients undergoing CABG surgery (Registration trial DRKS00008892 on DRKS). 


\section{Introduction}

57 In a theoretical approach to the pressure-flow (P-F) relationship in arterioles, these calculations are a simplification of the actual variable tissue characteristics in the vascular bed of an organ(Hoffman \& Spaan 1990). We demonstrated in an earlier study on the diastolic coronary PF relationship that the effective downstream pressure is not determined by coronary sinus

61 pressure (CSP) or left ventricular end-diastolic pressure (LVEDP) but by the critical occlusion pressure (COP) of the coronary vasculature, which was considerably higher than both parameters(Kazmaier et al. 2006). The zero flow pressure intercept as a measure of COP was extrapolated from the linear regression analysis of the instantaneous diastolic P-F relationship. However, the effects of isoflurane on the determinants of blood flow during coronary artery bypass graft (CABG) surgery are not completely understood. Earlier investigations yielded discrepant findings on the risk of myocardial ischemia due to the vasoactive potency of isoflurane. Some investigations found that the risk of myocardial ischemic events due to coronary flow misdistribution is increased when anesthesia is maintained with isoflurane(Buffington et al. 1987; Diana et al. 1993; Inoue et al. 1990; Khambatta et al. 1988; Priebe \& Foex 1987). In contrast, results from other investigators demonstrated that the risk of perioperative myocardial ischemia was not increased during isoflurane anesthesia compared with other volatile anesthetics or total intravenous anesthetic regimens(Leung et al. 1991; Pulley et al. 1991). Furthermore, in some studies, the vasoactive potency of isoflurane positively affected the regional distribution of coronary blood flow(Hartman et al. 1990; Kim et al. 1994). However, regarding volatile anesthetics, maximal increases in global coronary blood flow were obtained during isoflurane anesthesia(Crystal et al. 2000). According to the fact that volatile anesthetics(Landoni et al. 2013) and in particular isoflurane are beneficial for myocardial 
79 ischemia and has been shown to improve survival in cardiac surgery(Bignami et al. 2013; Chiari

80 et al. 2005; Ge et al. 2010; Lang et al. 2013), this study aimed at investigating the impact of 81 isoflurane on the diastolic P-F relationship and COP during CABG surgery. 


\section{Patients and Methods}

84

85

86

87

\section{Patients}

This study was approved by the University of Goettingen ethics committee in Goettingen, Germany (12/4/04) and conformed to the ethical principles of the Declaration of Helsinki. Written informed consent was obtained from all patients. Twenty patients (17 males and 3 females) with angiographically verified coronary artery disease (CAD) were studied following elective CABG surgery. Biometric and intraoperative data are presented in table 1. Patients with concomitant valvular heart disease or a lack of sinus rhythm at the start of the measurement period were excluded from this study. Antiarrhythmic and antihypertensive medications (except angiotensin-converting enzyme (ACE) inhibitors) were continued until the day of surgery. The pre-anesthetic medication consisted of $1.0 \mathrm{mg}$ of flunitrazepam per os on the evening prior to surgery and 60 minutes before the induction of general anesthesia. Patients were pre-operatively randomly assigned to receive either total intravenous anesthesia during the complete study period (control group) or an additional $0.4 \%$ volume of isoflurane (1.0 minimum anesthetic

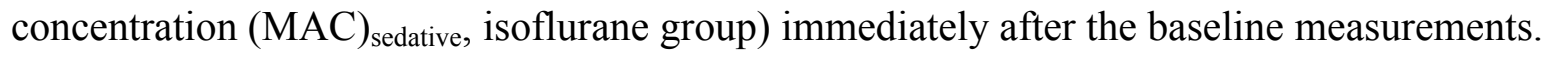

\section{Methods}

Before the induction of anesthesia, electrocardiogram leads were placed, and a 15-gauge catheter (PV2015L20; Pulsion GmbH, Munich, Germany) was placed in the femoral artery to measure the mean arterial pressure (MAP). Cardiac output measurements were performed with a transpulmonal thermodilution technique, pulse contour analysis (PiCCO, Pulsion GmbH, Munich, Germany) and blood sampling. Intravenous induction of anesthesia was performed with $2.0 \mu \mathrm{g} \mathrm{kg}^{-1}$ sufentanil and $0.1 \mathrm{mg} \mathrm{kg}^{-1}$ pancuronium bromide to facilitate endotracheal intubation. 
105 Subsequently, a central venous catheter (8.5 Fr., 4-lumen; ARROW GmbH, Erding, Germany)

106 was inserted via the right internal jugular vein to measure central venous pressure (CVP) and for

107 drug and fluid administration.

108 Maintenance of total intravenous anesthesia was performed by continuous infusion of sufentanil

$109\left(3.0 \mu \mathrm{g} \mathrm{kg}^{-1} \mathrm{~h}^{-1}\right)$ and additive boluses of midazolam if necessary. The patients' lungs were

110 ventilated by intermittent positive pressure ventilation (Cicero; Draeger GmbH, Lübeck,

111 Germany). The respiratory rate and minute volume were adjusted to achieve normocapnia.

112 During the measurement period, the fraction of inspired oxygen $\left(\mathrm{F}_{\mathrm{i}} \mathrm{O}_{2}\right)$ was 0.5 to avoid 113 hypoxemic events.

114 Extracorporeal circulation with standard techniques included two-stage venous cannulation

115 (Medtronic MC2TM, 91246C; 34/46Fr.; Medtronic Inc., Minneapolis, USA), central aortic 116 cannulation (Aortic Arch Cannula-Straight/Wire Inlay, 6.5 mm, A232-65; Stöckert Instrumente $117 \mathrm{GmbH}$, Munich, Germany) and membrane oxygenation (Hilite ${ }^{\circledR}$ 7000; Medizintechnik AG, 118 Stolberg, Germany). Surgery was performed during aortic cross-clamping and cardioplegic arrest 119 with combined anterograde and retrograde cold blood cardioplegia (Dr. Franz Köhler Chemie $120 \mathrm{GmbH}$, Alsbach-Hähnlein, Germany).

\section{Measurements}

122 The coronary vascular resistance (CVR) was calculated as the ratio of coronary perfusion 123 pressure (CPP) and coronary blood flow. CPP was calculated as the difference between the 124 upstream pressure and downstream pressure. The coronary upstream pressure was expressed as 125 the mean diastolic aortic pressure. CSP and LVEDP are generally used as equivalents of 126 coronary downstream pressure (reflecting the specific characteristics of the coronary anatomy). 
127 Baseline measurements were performed 15 minutes $\left(\mathrm{T}_{15}\right)$ after the discontinuation of 128 extracorporeal circulation under steady state conditions. Fifteen minutes after the end of the first measurement period $\left(\mathrm{T}_{30}\right)$, a second measurement period was performed in which patients in the

130 isoflurane group received $0.4 \%$ volume of isoflurane for 15 minutes. In the control group, the 131 anesthetic regimen did not change between the two measurement periods. All of the 132 measurements were performed prior to the reversal of heparin. At the beginning of each 133 measurement period, cardiac output was assessed by the transpulmonal thermodilution method as 134 the mean of three injections of $15 \mathrm{ml}$ of ice-cooled isotonic saline solution randomly distributed 135 over the respiratory cycle. During the short period (5 to 10 seconds) of coronary blood flow measurements, the patient was disconnected from the ventilator to avoid intrapleural pressure 137 changes and volume shifts that might influence the P-F relationships. In this study, to avoid 138 capacitance effects of the arterial vessel by opening phenomena, the analysis of the P-F 139 relationship only included data from the highest diastolic flow rate in the arterial bypass graft 140 until the end of diastole.

141 Flow measurements were performed using ultrasound and calculations based on the transit time 142 principle (Cardiomed 4008; Quick-Fit probes (size 2.0-3.0 mm), Medistim, Norway). The flow 143 in the left internal mammary artery and pressure measurements were recorded simultaneously 144 over a period of 5 seconds using analogue-digital converting devices with a sampling frequency 145 of $500 \mathrm{~Hz}$.

146 The measurements of aortic pressure and CSP were recorded via the cannulae for the 147 extracorporeal circuit and retrograde blood cardioplegia, respectively (coronary sinus cannula: 148 retrograde cardioplegia cannula RSH-M014S, 14 Fr; Chase Medical, Richardson, Texas, USA). 149 LVEDP values were obtained using a left atrial catheter (Jostra KLAP1751 pressure monitoring 
150 catheter, 5.0 Fr; Jostra AG, Hirrlingen, Germany) introduced via the upper right pulmonary vein

151 and positioned trans-mitrally into the left ventricle during the study period.

152 Arterial and coronary sinus blood samples were obtained immediately after each period of

153 coronary blood flow measurement for the determination of $\mathrm{pH}\left(\mathrm{pH}_{\mathrm{art}}, \mathrm{pH}_{\mathrm{cs}}\right)$, acid base status,

154 arterial and coronary sinus blood gas tensions $\left(\mathrm{P}_{\mathrm{a}} \mathrm{O}_{2}, \mathrm{P}_{\mathrm{cs}} \mathrm{O}_{2}, \mathrm{P}_{\mathrm{a}} \mathrm{CO}_{2}, \mathrm{P}_{\mathrm{cs}} \mathrm{CO}_{2}\right)$, oxygen saturation

$155\left(\mathrm{~S}_{\mathrm{a}} \mathrm{O}_{2}, \mathrm{~S}_{\mathrm{cs}} \mathrm{O}_{2}\right)$, hemoglobin $(\mathrm{Hb})$ and lactate concentrations (ABL 700; Radiometer Medical A/S,

156 Denmark). In the isoflurane group, additional coronary sinus blood samples were obtained after

157 the second measurement period for the determination of isoflurane plasma concentrations.

\section{Calculations}

159 The cardiac index (CI), stroke volume index (SVI) and systemic vascular resistance index

160 (SVRI) were calculated according to standard formulae. The critical occlusion pressure was

161 calculated by extrapolation of the linear regression analysis of the diastolic part of the aortic P-F

162 loop to the zero flow pressure intercept (2). The mean LVEDP was assessed by analysis of the

163 left ventricular pressure curve for every beat during the study period. The CSP was calculated as

164 the mean CSP of the entire period of flow measurements.

\section{Statistics}

166 Statistical procedures were performed using the Statistical Package for the Social Sciences 167 (SPSS) (SPSS 17.0 for MAC; SPSS Inc., Chicago, Illinois, USA). Results are expressed as 168 medians and ranges. Two continuous variables were compared using Mann-Whitney test. Linear 169 regression analysis was performed using flow as the dependent variable and diastolic aortic 170 pressure as the independent variable. A p-value less than 0.05 was considered to be significant. 


\section{Results}

173 The biometric and perioperative data of the studied patients were not different between both

174 groups (table 1). The data from five consecutive heart beats were analyzed for each patient; none

175 of the patients had to be excluded due to missing data or artifacts in hemodynamics and flow

176 measurements.

177 Table 1. Biometric and intraoperative data. Results are presented as medians and ranges, if 178 required.

\begin{tabular}{|c|c|c|c|}
\hline & Control $(n=10)$ & Isoflurane $(n=10)$ & p-value \\
\hline Age (years) & $70(58-79)$ & $71(51-81)$ & 0.44 \\
\hline Weight (kg) & $80(60-92)$ & $75(60-103)$ & 0.68 \\
\hline Height (cm) & $168(153-82)$ & $168(156-180)$ & 0.68 \\
\hline Gender (male/female) & $8 / 2$ & $9 / 1$ & 0.53 \\
\hline Body surface area $\left(\mathrm{m}^{2}\right)$ & $1.89(1.57-2.12)$ & $1.89(1.59-2.09)$ & 0.97 \\
\hline Coronary artery disease & $\begin{array}{l}3 \text { vessel disease, } n=7 \\
2 \text { vessel disease, } n=3\end{array}$ & $\begin{array}{l}3 \text { vessel disease, } n=6 \\
2 \text { vessel disease, } n=3 \\
1 \text { vessel disease, } n=1\end{array}$ & \\
\hline Grafts (n) & $4(3-5)$ & $4(2-5)$ & \\
\hline Aortic clamping time (minutes) & $78(61-92)$ & $85(45-112)$ & 0.68 \\
\hline Reperfusion time (minutes) & $44(32-65)$ & $40(26-66)$ & 0.48 \\
\hline
\end{tabular}

179

180 Systemic hemodynamics 
181 In both groups, GEDI and SVV (parameters of volume status), as well as LVEDP, CFI, and

182 EVLWI, did not change during the entire measurement period and were not different between

183 groups. In the control group, MAP, CI, HR and SVRI did not change during the entire study

184 period. In contrast to measurements in the control group, the application of $1.0 \mathrm{MAC}_{\text {sedative }}$

185 isoflurane decreased MAP from 69 to $57 \mathrm{mmHg}(17 \%)$ and SVRI from 1730 to 1364 dyn sec

$186 \mathrm{~cm}^{-5} \mathrm{~m}^{2}(21 \%)$ but had no effect on HR and CI. The systemic hemodynamic data are summarized

187 in table 2 (Table $2 \mathrm{a}$ and Table $2 \mathrm{~b}$ ).

188 Table 2. Hemodynamic data. Results are presented as medians and ranges.

\begin{tabular}{|c|c|c|c|c|c|c|}
\hline & Control & & & Isoflurane & & \\
\hline & $\mathrm{T}_{15}$ & $\mathrm{~T}_{30}$ & $\begin{array}{l}\text { Control } \\
\text { T15 vs } \\
\text { T30 (p- } \\
\text { value) }\end{array}$ & $\mathrm{T}_{15}$ & $\mathrm{~T}_{30}$ & $\begin{array}{l}\text { Isoflurane } \\
\text { T15 vs } \\
\text { T30 (p- } \\
\text { value) }\end{array}$ \\
\hline CI $\left(1 \min ^{-1} \mathrm{~m}^{-2}\right)$ & $\begin{array}{ll}2.9 & (2.3- \\
3.6) & \end{array}$ & $\begin{array}{ll}2.7 & (2.1- \\
3.2) & \end{array}$ & 0.11 & $\begin{array}{ll}2.7 & (1.6- \\
5.7) & \end{array}$ & \begin{tabular}{|ll}
2.6 & $(1.9-$ \\
$5.8)$ & \\
\end{tabular} & 0.28 \\
\hline $\operatorname{HR}\left(\min ^{-1}\right)$ & $\begin{array}{|ll|}89 & (53- \\
106) & \end{array}$ & $90(56-106)$ & 0.65 & $\begin{array}{l}99 \quad(76- \\
112)\end{array}$ & $\begin{array}{ll}88 & (74- \\
100) & \end{array}$ & 0.15 \\
\hline MAP (mmHg) & $65(47-80)$ & $66(56-84)$ & 0.06 & $69(59-85)$ & $57(48-59)$ & 0.005 \\
\hline $\begin{array}{l}\text { MDAP } \\
(\mathrm{mmHg})\end{array}$ & $57(45-64)$ & $60(43-71)$ & 0.06 & $62(53-79)$ & $50(45-57)$ & 0.005 \\
\hline DDT (ms) & $\begin{array}{l}447 \quad(257- \\
1215)\end{array}$ & $\begin{array}{ll}489 & (366- \\
1070)\end{array}$ & 0.60 & $\begin{array}{l}721 \quad(240- \\
919)\end{array}$ & $\begin{array}{l}567 \quad(339- \\
937)\end{array}$ & 0.33 \\
\hline CVP (mmHg) & $9(7-16)$ & $9(7-16)$ & 1.0 & $10(7-12)$ & $10(7-13)$ & 0.82 \\
\hline
\end{tabular}




\begin{tabular}{|c|c|c|c|c|c|c|}
\hline $\mathrm{CSP}(\mathrm{mmHg})$ & $14(8-18)$ & $13(7-18)$ & 0.39 & $10(5-20)$ & $10(6-19)$ & 0.44 \\
\hline $\begin{array}{l}\text { SVRI (dyn sec } \\
\mathrm{cm}^{-5} \mathrm{~m}^{2} \text { ) }\end{array}$ & $\begin{array}{l}1555 \\
(809- \\
2454)\end{array}$ & $\begin{array}{l}1716 \\
(1355- \\
2193)\end{array}$ & 0.31 & $\begin{array}{l}1730 \\
(850- \\
2969)\end{array}$ & $\begin{array}{l}1364(699- \\
1965)\end{array}$ & 0.04 \\
\hline GEDI $\left(\mathrm{ml} \mathrm{m}^{-2}\right)$ & $\begin{array}{l}642 \quad(541- \\
895)\end{array}$ & $\begin{array}{ll}652 \quad(594- \\
883)\end{array}$ & 0.78 & $\begin{array}{l}642 \quad(457- \\
834)\end{array}$ & $\begin{array}{l}617 \quad(479- \\
802)\end{array}$ & 0.92 \\
\hline $\begin{array}{l}\text { EVLWI ( } \mathrm{ml} \mathrm{m}^{-} \\
\left.{ }^{2}\right)\end{array}$ & $\begin{array}{l}6.8 \quad(5.7- \\
10.0)\end{array}$ & $\begin{array}{ll}6.3 \quad(5.0- \\
8.7) & \end{array}$ & 0.62 & $\begin{array}{l}7.4 \quad(4.0- \\
10.7)\end{array}$ & $\begin{array}{l}7.0 \quad(4.3- \\
10.0)\end{array}$ & 0.16 \\
\hline $\begin{array}{l}\text { LVEDP } \\
(\mathrm{mmHg})\end{array}$ & $16(8-33)$ & $15(8-30)$ & 0.09 & $11(8-37)$ & $13(9-22)$ & 0.80 \\
\hline SVV (\%) & \begin{tabular}{|l|}
$11(6-17)$ \\
\end{tabular} & $12(5-18)$ & 0.64 & \begin{tabular}{|l}
$12(5-19)$ \\
\end{tabular} & $14(8-16)$ & 0.43 \\
\hline $\begin{array}{l}\mathrm{dp} / \mathrm{dt}_{\max } \\
\left(\mathrm{mmHg} \mathrm{s}^{-1}\right)\end{array}$ & $\begin{array}{l}766 \quad(507- \\
1063)\end{array}$ & $\begin{array}{l}763 \quad(500- \\
887)\end{array}$ & 0.65 & $\begin{array}{l}748 \quad(510- \\
1350)\end{array}$ & $\begin{array}{l}651 \quad(340- \\
1143)\end{array}$ & 0.02 \\
\hline $\mathrm{CFI}\left(\mathrm{min}^{-1}\right)$ & $\begin{array}{l}4.2 \quad(3.5- \\
5.0)\end{array}$ & $\begin{array}{ll}3.7 & (2.8- \\
5.0) & \end{array}$ & 0.05 & $\begin{array}{l}4.6 \quad(2.5- \\
8.1)\end{array}$ & $\begin{array}{l}3.9 \quad(3.1- \\
7.4)\end{array}$ & 0.16 \\
\hline $\mathrm{COP}(\mathrm{mmHg})$ & $39(23-48)$ & $42(28-44)$ & 0.25 & $35(26-59)$ & $34(27-42)$ & 0.11 \\
\hline $\begin{array}{l}\text { FLOW } \\
(\mathrm{ml} / \mathrm{min})\end{array}$ & $26(10-38)$ & $22(9-53)$ & 0.72 & $29(7-68)$ & $23(11-50)$ & 0.24 \\
\hline Slope (B1) & \begin{tabular}{|l}
1.36 \\
$(0.48-$ \\
$2.71)$
\end{tabular} & $\begin{array}{l}1.29(0.46- \\
2.10)\end{array}$ & 0.49 & $\begin{array}{l}0.94 \\
(0.50- \\
4.82)\end{array}$ & $\begin{array}{l}2.03(0.56- \\
4.41)\end{array}$ & 0.02 \\
\hline from & 0.74 & $0.78 \quad(0.48-$ & 0.49 & 1.06 & $0.51(0.23-$ & 0.007 \\
\hline
\end{tabular}




\begin{tabular}{|c|c|c|c|c|c|c|}
\hline Slope 1/B1 & $\begin{array}{l}(0.37- \\
2.10)\end{array}$ & $2.17)$ & & $\begin{array}{l}(0.21- \\
2.02)\end{array}$ & 1.79) & \\
\hline CVR from CSP & $\begin{array}{l}1.73 \\
(1.21- \\
3.92)\end{array}$ & $\begin{array}{l}1.83(0.94- \\
5.51)\end{array}$ & 0.69 & $\begin{array}{l}1.80 \\
(0.78- \\
8.83)\end{array}$ & $\begin{array}{l}1.35(0.81- \\
3.35)\end{array}$ & 0.30 \\
\hline $\begin{array}{l}\text { CVR from } \\
\text { LVEDP }\end{array}$ & $\begin{array}{l}1.66 \\
(0.81- \\
4.05)\end{array}$ & $\begin{array}{l}1.86(0.61- \\
5.64)\end{array}$ & 0.49 & $\begin{array}{l}1.68 \\
(0.79- \\
5.38)\end{array}$ & $\begin{array}{l}1.77(0.73- \\
3.13)\end{array}$ & 0.06 \\
\hline $\begin{array}{l}\text { CVR from } \\
\text { COP }\end{array}$ & $\begin{array}{l}0.74 \\
(0.37- \\
2.07)\end{array}$ & $\begin{array}{l}0.78(0.46- \\
2.13)\end{array}$ & 0.44 & $\begin{array}{l}1.06 \\
(0.21- \\
2.02)\end{array}$ & $\begin{array}{l}0.51(0.23- \\
1.79)\end{array}$ & 0.006 \\
\hline
\end{tabular}

189

190 Table 3. Hemodynamic data; Isoflurane vs control.

\begin{tabular}{|l|l|l|}
\hline & Control vs Isoflurane & Control vs Isoflurane \\
& T15 (p-value) & T30 (p-value) \\
\hline CI (l min-1 m-2) & 0.96 & 0.90 \\
\hline HR (min-1) & 0.90 & 0.85 \\
\hline MAP (mmHg) & 0.06 & 0.009 \\
\hline MDAP (mmHg) & 0.06 & 0.01 \\
\hline DDT (ms) & 0.56 & 0.90 \\
\hline CVP (mmHg) & 0.96 & 0.83 \\
\hline CSP (mmHg) & 0.16 & 0.11 \\
\hline SVRI (dyn sec cm-5 m2) & 0.51 & 0.05 \\
\hline
\end{tabular}




\begin{tabular}{|l|l|l|}
\hline GEDI (ml m-2) & 0.69 & 0.27 \\
\hline EVLWI (ml m-2) & 0.31 & 0.41 \\
\hline LVEDP (mmHg) & 0.34 & 0.47 \\
\hline SVV (\%) & 0.96 & 0.57 \\
\hline dp/dtmax (mmHg s-1) & 0.96 & 0.57 \\
\hline CFI (min-1) & 0.56 & 0.76 \\
\hline COP (mmHg) & 0.87 & 0.11 \\
\hline FLOW (ml/min) & 0.38 & 0.79 \\
\hline Slope (B1) & 0.79 & 0.05 \\
\hline CVR from Slope 1/B1 & 0.87 & 0.14 \\
\hline CVR from CSP & 0.83 & 0.28 \\
\hline CVR from LVEDP & 0.85 & 0.39 \\
\hline CVR from COP & 0.73 & 0.10 \\
\hline
\end{tabular}

191

192 The diastolic flow and COP during CABG surgery did not differ between measurement periods 193 or groups. In the control group, COP exceeded LVEDP by $244 \%$ and $280 \%$, respectively. In the 194 control group, COP exceeded CSP by $279 \%$ and $323 \%$, respectively. In the isoflurane group, 195 similar results were found with $318 \%, 262 \%, 350 \%$ and $340 \%$, respectively.

196 The application of isoflurane decreased the MDAP from $62 \mathrm{mmHg}$ to $50 \mathrm{mmHg}$, whereas 197 MDAP did not change in the control group.

198 Consequently, CVR changes were only observed in the isoflurane group (if calculated using 199 COP and LVEDP but not CSP). Considerable differences in CVR were observed depending on 200 the downstream pressure (COP, LVEDP or CSP) used in the formula. With CSP as a measure of 
201 downstream pressure, CVR did not change significantly in either group. In the control group, the

202 CVR values were 1.73 and $1.83 \mathrm{mmHg} \mathrm{ml}^{-1}$ minute, while those in the isoflurane group were 1.8

203 and $1.35 \mathrm{mmHg} \mathrm{ml}^{-1}$ minute. Similar findings were observed for CVR calculated with LVEDP in

204 both groups.

205 In contrast to these findings, using COP in the formula indicated that CVR was decreased after 206 the application of isoflurane from 1.06 to $0.51 \mathrm{mmHg} \mathrm{ml}^{-1}$ minute. In the control group, CVR 207 was calculated using COP, and no differences were observed $\left(0.74\right.$ and $0.78 \mathrm{mmHg} \mathrm{ml}^{-1}$ minute).

208 As expected, using COP for the calculation of CVR resulted in significantly lower values for 209 CVR than using LVEDP or CSP. The CVR values were identical when calculated according to 210 the slope of the instantaneous diastolic P-F relationship. The diastolic flow, COP and CVR 211 calculations are summarized in table 2 (Table $2 \mathrm{a}$ and Table $2 \mathrm{~b}$ ).

212 Arterial blood gas analyses and acid base status also did not differ between groups and remained 213 unchanged during the measurement period. For the coronary sinus blood gas samples, $\mathrm{S}_{\mathrm{cs}} \mathrm{O}_{2}$ $214 \mathrm{p}_{\mathrm{cs}} \mathrm{O}_{2}, \mathrm{p}_{\mathrm{cs}} \mathrm{CO}_{2}, \mathrm{pH}_{\mathrm{cs}}, \mathrm{BE}_{\mathrm{cs}}$ and $\mathrm{SBIC}_{\mathrm{cs}}$ and lactate did not differ between the measurement periods 215 in the control group. In contrast to these findings, the application of isoflurane led to a significant 216 increase in $\mathrm{S}_{\mathrm{cs}} \mathrm{O}_{2}$ and $\mathrm{p}_{\mathrm{cs}} \mathrm{O}_{2}$ by $22 \%$ and $22 \%$, respectively, indicating a reduced myocardial

217 oxygen extraction. This decrease in myocardial oxygen extraction was not associated with a 218 significant change in MLE. The arterial and coronary sinus blood gas analysis results are 219 presented in table 3 (Table $3 a$ and Table3b).

Table 4. Arterial and coronary sinus blood gas analyses. Results are presented as medians and ranges.

\begin{tabular}{|c|c|c|c|c|c|c|}
\hline & \multicolumn{2}{|c|}{ Control } & & \multicolumn{2}{|c|}{ Isoflurane } & \\
\hline & $\mathrm{T}_{15}$ & $\mathrm{~T}_{30}$ & $\begin{array}{c}\text { Control } \\
\mathrm{T}_{15} \mathrm{vs} \mathrm{T}_{30}\end{array}$ & $\mathrm{~T}_{15}$ & $\mathrm{~T}_{30}$ & $\begin{array}{l}\text { Isoflurane } \\
\mathrm{T}_{15} \text { vs } \mathrm{T}_{30}\end{array}$ \\
\hline $\mathrm{Hb}_{\text {art }}(\mathrm{g} / \mathrm{dl})$ & $9.1(7.5-10.0)$ & $9.0(7.8-10.9)$ & 0.51 & $9.2(8.1-10.3)$ & $9.2(7.6-11.6)$ & 0.91 \\
\hline
\end{tabular}




\begin{tabular}{|c|c|c|c|c|c|c|}
\hline $\mathrm{S}_{\mathrm{a}} \mathrm{O}_{2}(\%)$ & $\begin{array}{c}99(94.1- \\
99.6) \\
\end{array}$ & 99 (93.7-99.9) & 1.0 & 99 (98.7-99.7) & 99 (97.2-99.7) & 0.31 \\
\hline $\mathrm{P}_{\mathrm{a}} \mathrm{O}_{2}(\mathrm{mmHg})$ & $163(71-298)$ & $153(75-364)$ & 0.43 & $200(124-293)$ & $213(141-277)$ & 0.28 \\
\hline $\mathrm{P}_{\mathrm{a}} \mathrm{CO}_{2}(\mathrm{mmHg})$ & $46(38-54)$ & $48(39.7-51.7)$ & 0.08 & $43(35-55)$ & $44(34-50)$ & 0.82 \\
\hline $\mathrm{pH}_{\text {art. }}$ & $\begin{array}{c}7.35(7.24- \\
7.41)\end{array}$ & $\begin{array}{c}7.35(7.22- \\
7.38)\end{array}$ & 0.08 & $\begin{array}{c}7.35(7.24- \\
7.44)\end{array}$ & $7.34(7.28-7.45)$ & 1.0 \\
\hline $\mathrm{BE}_{\text {art. }}(\mathrm{mmol} / \mathrm{l})$ & $-0.4(-7.6-1.3)$ & $-1.2(-7.2-1.1)$ & 0.55 & $-1.4(-4.4-1.2)$ & $-2.4(-3.6-0.1)$ & 0.31 \\
\hline $\mathrm{SBIC}_{\text {art. }}(\mathrm{mmol} / \mathrm{l})$ & $\begin{array}{c}24.1(18.2- \\
25.5)\end{array}$ & $\begin{array}{c}23.5(18.5- \\
25.5)\end{array}$ & 0.58 & $\begin{array}{c}22.7(20.7- \\
24.2)\end{array}$ & $22.4(21.4-24.6)$ & 0.43 \\
\hline $\mathrm{S}_{\mathrm{cs}} \mathrm{O}_{2}(\%)$ & $49(23.5-82.9)$ & $46(39.3-74.9)$ & 0.49 & $46(29.7-74.5)$ & $56(33.1-80.3)$ & 0.05 \\
\hline $\mathrm{P}_{\mathrm{cs}} \mathrm{O}_{2}(\mathrm{mmHg})$ & $26(19-51)$ & $27(24-43)$ & 0.70 & $27(19-44)$ & $33(22-49)$ & 0.006 \\
\hline $\mathrm{P}_{\mathrm{cs}} \mathrm{CO}_{2}(\mathrm{mmHg})$ & $56(38-64)$ & $58(48-62)$ & 0.06 & $54(38-66)$ & $55(40-64)$ & 1.0 \\
\hline $\mathrm{pH}_{\mathrm{cs}}$ & $\begin{array}{c}7.30(7.14- \\
7.35) \\
\end{array}$ & $\begin{array}{c}7.30(7.17- \\
7.32) \\
\end{array}$ & 0.13 & $\begin{array}{c}7.30(7.19- \\
7.42) \\
\end{array}$ & $7.28(7.23-7.40)$ & 0.30 \\
\hline $\mathrm{BE}_{\mathrm{cs}}(\mathrm{mmol} / \mathrm{l})$ & $0.3(-7.9-2.0)$ & $-0.1(-6.8-1.9)$ & 0.91 & $-1.4(-3.9-0.7)$ & $-2.2(-3.4-0.2)$ & 0.02 \\
\hline $\mathrm{SBIC}_{\mathrm{cs}}(\mathrm{mmol} / \mathrm{l})$ & $\begin{array}{c}23.9(17.0- \\
25.3) \\
\end{array}$ & $\begin{array}{c}23.7(18.1- \\
25.2) \\
\end{array}$ & 0.84 & $\begin{array}{c}22.6(20.8- \\
24.3 \\
\end{array}$ & $21.9(21.3-24.2)$ & 0.03 \\
\hline Lactate $_{\mathrm{cs}}(\mathrm{mmol} / \mathrm{l})$ & $1.0(0.6-5.8)$ & $1.0(0.5-5.3)$ & 0.16 & $1.8(1.0-3.0)$ & $2.0(0.8-2.7)$ & 0.39 \\
\hline $\begin{array}{l}\text { Isoflurane }{ }_{\mathrm{cs}} \\
(\mu \mathrm{g} / \mathrm{dl})\end{array}$ & 0 & 0 & & 0 & $1.4(0.8-2.3)$ & \\
\hline
\end{tabular}

223 Table 5. Arterial and coronary sinus blood gas analyses; Isoflurane vs Control.

\begin{tabular}{|l|l|l|}
\hline & $\begin{array}{l}\text { Control vs Isoflurane } \\
\mathrm{T}_{15}(\mathrm{p} \text {-value) }\end{array}$ & $\begin{array}{l}\text { Control vs Isoflurane } \\
\mathrm{T}_{30} \text { (p-value) }\end{array}$ \\
\hline $\mathrm{Hb}_{\mathrm{art}}(\mathrm{g} / \mathrm{dl})$ & 0.43 & 0.57 \\
\hline $\mathrm{S}_{\mathrm{a}} \mathrm{O}_{2}(\%)$ & 0.17 & 0.32 \\
\hline $\mathrm{P}_{\mathrm{a}} \mathrm{O}_{2}(\mathrm{mmHg})$ & 0.32 & 0.08 \\
\hline $\mathrm{P}_{\mathrm{a}} \mathrm{CO}_{2}(\mathrm{mmHg})$ & 0.39 & 0.12 \\
\hline $\mathrm{pH}_{\text {art. }}$ & 0.35 & 0.68 \\
\hline $\mathrm{BE}_{\text {art. }}(\mathrm{mmol} / \mathrm{l})$ & 0.22 & 0.25 \\
\hline
\end{tabular}




\begin{tabular}{|l|l|l|}
\hline $\mathrm{SBIC}_{\text {art. }}(\mathrm{mmol} / \mathrm{l})$ & 0.19 & 0.25 \\
\hline $\mathrm{S}_{\mathrm{cs}} \mathrm{O}_{2}(\%)$ & 0.85 & 0.17 \\
\hline $\mathrm{P}_{\mathrm{cs}} \mathrm{O}_{2}(\mathrm{mmHg})$ & 0.58 & 0.17 \\
\hline $\mathrm{P}_{\mathrm{cs}} \mathrm{CO}_{2}(\mathrm{mmHg})$ & 0.80 & 0.35 \\
\hline $\mathrm{pH}_{\mathrm{cs}}$ & 0.79 & 0.85 \\
\hline $\mathrm{BE}_{\mathrm{cs}}(\mathrm{mmol} / \mathrm{l})$ & 0.53 & 0.17 \\
\hline $\mathrm{SBIC}_{\mathrm{cs}}(\mathrm{mmol} / \mathrm{l})$ & 0.63 & 0.16 \\
\hline Lactate $_{\mathrm{cs}}(\mathrm{mmol} / \mathrm{l})$ & 0.06 & 0.03 \\
\hline Isoflurane & & \\
\hline
\end{tabular}




\section{Discussion}

226 This study investigated the influence of short-term isoflurane administration on the instantaneous

227 diastolic P-F relationship for the calculation of CVR and COP in patients undergoing elective

228 CABG surgery. CVR was calculated with different techniques. First, CVR was calculated with

229 conventional formulas using MDAP as the upstream pressure and LVEDP or CSP as the

230 downstream pressures. Second, CVR was calculated from the instantaneous diastolic P-F

231 relationship using either the slope of the linear diastolic portion or the linear extrapolation of this

232 slope to zero flow (with COP for the calculation of downstream pressure). COP was about two to

233 three times higher than the generally used downstream pressures (CSP or LVEDP) and was not

234 influenced by isoflurane. This result may be explained by a waterfall phenomenon in the

235 coronary circulation(Kazmaier et al. 2006; Maas et al. 2012). In addition, CVR decreased

236 following the application of isoflurane only when the instantaneous P-F relationship was used in

237 the calculation. The CVR decreases derived from the P-F relationship showed excellent

238 concordance. The finding of reduced CVR was supported by decreased myocardial oxygen

239 extraction in the isoflurane group.

240 COP is calculated by linear extrapolation of the instantaneous diastolic P-F relationship in the

241 respective grafts to zero flow. Similarly, but without extrapolation to zero flow, CVR can be

242 assessed by the slope of the instantaneous diastolic P-F relationship. The determination COP in

243 IMAB grafts for calculating CPP and CVR revealed that both CSP and LVEDP (generally used

244 as measures of downstream pressure to calculate CPP and CVR) underestimate the effective

245 downstream pressure and, consequently, CVR. 
246 The concept of using COP to define the effective downstream pressure is convincing because

247 basic physiology predicts that blood flow ceases if the difference between the upstream and

248 downstream pressure in a vascular tree equals zero; thus, the arterial pressure at zero flow

249 represents the effective downstream pressure of organ blood flow(Hoffman \& Spaan 1990).

250 Earlier experimental and clinical studies investigating the effects of massive coronary

251 vasodilatation on diastolic P-F demonstrated that the linearity of the relationship between

252 pressure and flow velocity was not influenced. The slope increased and COP decreased after

253 vasodilatation in these studies(Dole et al. 1984; Klocke et al. 1981; Nanto et al. 2001).

254 Intracoronary injections of angiographic contrast medium or adenosine triphosphate depressed

255 vasomotor activity and induced an atrioventricular blockade followed by a non-physiological

256 increase in diastole.

257 In contrast to these studies, we found a remarkable decrease in CVR only when COP was used to

258 calculate the effective perfusion pressure and CVR. As expected, the calculation of CVR using 259 the instantaneous diastolic P-F relationship yielded identical results. Using CSP and LVEDP as 260 downstream pressures to calculate CPP and CVR revealed unchanged CPP and CVR. CSP and 261 LVEDP may not adequately reflect downstream pressure(Kazmaier et al. 2006). In earlier 262 studies, blood flow velocity measurements were performed (in contrast to our study in which

263 blood flow was assessed). The relative accuracy of flow probes has been described and validated 264 (within $\pm 2 \%$ )(Beldi et al. 2000; Groom et al. 2001). Flow velocity is linearly related to flow only 265 if the diameter of the vessel in which the measurements are performed is calculated. Studies have 266 demonstrated that the cross-sectional areas of epicardial coronary vessels are nearly independent 267 of pressure and flow(Douglas \& Greenfield 1970; Klocke et al. 1980). Thus, differences in 
268 results are probably not due to different measurement techniques but to different study 269 conditions.

270 Furthermore, it remains questionable whether the CVR and COP results assessed in the 271 previously mentioned studies during maximal coronary vasodilatation and atrioventricular 272 blockade reflect physiologic conditions in human coronary circulation as presented in our study.

273 Most studies on intraoperative myocardial blood flow measurements are focused on graft 274 patency(D'Ancona et al. 2000; Leung et al. 1991; Takami \& Ina 2001; Walpoth et al. 1998). In 275 our first study, we demonstrated the feasibility of calculating COP, CPP and CVR by assessing 276 the instantaneous P-F relationship in coronary bypass grafts(Kazmaier et al. 2006). In another

277 study, a negative correlation was observed between COP and residual myocardial viability after 278 angioplasty in patients with acute myocardial infarction(Shimada et al. 2003). In a group of 279 similar patients, short- and long-term myocardial outcomes were closely correlated with the 280 deceleration time of diastolic coronary flow velocity(Furber et al. 2004; Yamamuro et al. 2002). 281 Several studies have demonstrated the myocardial protective effects of isoflurane in patients 282 undergoing CABG surgery. Nevertheless, in our study, isoflurane did not influence COP (in 283 contrast to CPP and CVR). Additionally, CPP was considerably overestimated if CSP or 284 LVEDP, which were not influenced by isoflurane, were used in the calculations.

285 In addition to providing a more valid calculation of CPP using COP for downstream pressure, 286 our study also has clinical implications. After short-term application of isoflurane with sub287 anesthetic concentrations, COP was unchanged, but MDAP decreased significantly, resulting in a 288 remarkable decrease in CPP. Despite this decrease in CPP, coronary flow remained unchanged, 289 which is due to a considerable decrease in CVR. These effects could only be measured by the 290 calculation of CVR using the diastolic instantaneous P-F relationship (in contrast to the standard 
291 formula). Undiminished flow was accompanied by an unaltered CI. Nevertheless, we observed

292 increased $\mathrm{ScsO}_{2}$, which is an indicator of hyper-perfusion.

293 Our study had a few limitations that may affect the interpretation of these results.

294 The second measurement in the isoflurane group was performed after 15 minutes of isoflurane 295 application. The expiratory isoflurane concentrations reached $95 \%$ of the inspiratory 296 concentrations indicating steady state conditions in the isoflurane blood concentrations at 1.0 $297 \mathrm{MAC}_{\text {sedative }}$ Nevertheless, we cannot exclude the possibility that the myocardial uptake of 298 isoflurane was incomplete resulting in unstable concentrations in the myocardial tissue. Studies 299 on long-term applications and dose-response relationships of isoflurane may provide further 300 insights on the effects of isoflurane on the instantaneous P-F relationship in arterial coronary 301 bypass grafts. 


\section{Conclusions}

303 Short-term application of isoflurane with sub-sedative concentrations markedly increased the

304 slope of the instantaneous diastolic P-F relationship in arterial coronary bypass grafts. This

305 finding implies a distinct decrease in CVR in patients undergoing CABG surgery that cannot be

306 observed with the conventional CVR calculations using MDAP as the upstream pressure and

307 LVEDP or CSP as the downstream pressure. The simultaneous decrease in myocardial oxygen 308 extraction supports the validity of CVR calculation using the slope of the diastolic P-F

309 relationship possibly indicating hyper-perfusion of the myocardium. Thus, the technique

310 provides a more rational approach for the measurement of regional coronary vascular perfusion.

311 Independent of the anesthetic, CSP and LVEDP greatly underestimated the effective downstream

312 pressure and COP leading to a systematic overestimation of CPP. This result can be explained by

313 a vascular waterfall phenomenon in the coronary circulation. However, in contrast to CVR, COP

314 (the more reliable downstream pressure) is not influenced by isoflurane. 


\section{Acknowledgments}

316 The authors thank the staff of the Department of Anesthesiology all of whom were involved in

317 patient care and monitoring. 


\section{References}

Beldi G, Bosshard A, Hess OM, Althaus U, and Walpoth BH. 2000. Transit time flow measurement: experimental validation and comparison of three different systems. Ann Thorac Surg 70:212217.

Bignami E, Greco T, Barile L, Silvetti S, Nicolotti D, Fochi O, Cama E, Costagliola R, Landoni G, BiondiZoccai G, and Zangrillo A. 2013. The effect of isoflurane on survival and myocardial infarction: a meta-analysis of randomized controlled studies. J Cardiothorac Vasc Anesth 27:50-58. 10.1053/j.jvca.2012.06.007

Buffington CW, Romson JL, Levine A, Duttlinger NC, and Huang AH. 1987. Isoflurane induces coronary steal in a canine model of chronic coronary occlusion. Anesthesiology 66:280-292.

Chiari PC, Bienengraeber MW, Pagel PS, Krolikowski JG, Kersten JR, and Warltier DC. 2005. Isoflurane protects against myocardial infarction during early reperfusion by activation of phosphatidylinositol-3-kinase signal transduction: evidence for anesthetic-induced postconditioning in rabbits. Anesthesiology 102:102-109.

Crystal GJ, Zhou X, Gurevicius J, Czinn EA, Salem MR, Alam S, Piotrowski A, and Hu G. 2000. Direct coronary vasomotor effects of sevoflurane and desflurane in in situ canine hearts. Anesthesiology 92:1103-1113.

D'Ancona G, Karamanoukian HL, Ricci M, Bergsland J, and Salerno TA. 2000. Graft patency verification in coronary artery bypass grafting: principles and clinical applications of transit time flow measurement. Angiology 51:725-731.

Diana P, Tullock WC, Gorcsan J, 3rd, Ferson PF, and Arvan S. 1993. Myocardial ischemia: a comparison between isoflurane and enflurane in coronary artery bypass patients. Anesth Analg 77:221-226.

Dole WP, Richards KL, Hartley CJ, Alexander GM, Campbell AB, and Bishop VS. 1984. Diastolic coronary artery pressure-flow velocity relationships in conscious man. Cardiovasc Res 18:548-554.

Douglas JE, and Greenfield JC, Jr. 1970. Epicardial coronary artery compliance in the dog. Circ Res 27:921-929.

Furber AP, Prunier F, Nguyen HC, Boulet S, Delepine S, and Geslin P. 2004. Coronary blood flow assessment after successful angioplasty for acute myocardial infarction predicts the risk of longterm cardiac events. Circulation 110:3527-3533. 10.1161/01.cir.0000148686.95696.1e

Ge ZD, Pravdic D, Bienengraeber M, Pratt PF, Jr., Auchampach JA, Gross GJ, Kersten JR, and Warltier DC. 2010. Isoflurane postconditioning protects against reperfusion injury by preventing mitochondrial permeability transition by an endothelial nitric oxide synthase-dependent mechanism. Anesthesiology 112:73-85. 10.1097/ALN.0b013e3181c4a607

Groom R, Tryzelaar J, Forest R, Niimi K, Cecere G, Donegan D, Katz S, Weldner P, Quinn R, Braxton J, Blank S, Kramer R, and Morton J. 2001. Intra-operative quality assessment of coronary artery bypass grafts. Perfusion 16:511-518.

Hartman JC, Kampine JP, Schmeling WT, and Warltier DC. 1990. Volatile anesthetics and regional myocardial perfusion in chronically instrumented dogs: halothane versus isoflurane in a singlevessel disease model with enhanced collateral development. J Cardiothorac Anesth 4:588-603. Hoffman JI, and Spaan JA. 1990. Pressure-flow relations in coronary circulation. Physiol Rev 70:331-390. Inoue K, Reichelt W, el-Banayosy A, Minami K, Dallmann G, Hartmann N, and Windeler J. 1990. Does isoflurane lead to a higher incidence of myocardial infarction and perioperative death than enflurane in coronary artery surgery? A clinical study of 1178 patients. Anesth Analg 71:469-474. 
361

362

363

364

365

366

367

368

369

370

371

372

373

374

375

376

377

378

379

380

381

382

383

384

385

386

387

388

389

390

391

392

393

394

395

396

397

398

399

400

401

402

403

404

405

406

407

408

Kazmaier S, Hanekop GG, Grossmann M, Dorge H, Gotze K, Schondube F, Quintel M, and Weyland A. 2006. Instantaneous diastolic pressure-flow relationship in arterial coronary bypass grafts. Eur J Anaesthesio/ 23:373-379. 10.1017/s0265021505001985

Khambatta HJ, Sonntag H, Larsen R, Stephan H, Stone JG, and Kettler D. 1988. Global and regional myocardial blood flow and metabolism during equipotent halothane and isoflurane anesthesia in patients with coronary artery disease. Anesth Analg 67:936-942.

Kim YD, Heim K, Wang YN, Lees D, and Myers AK. 1994. Effects of isoflurane on regional coronary blood flow and myocardial tissue pressure in chronically instrumented dogs. Anesthesiology 81:875887.

Klocke FJ, Ellis AK, and Orlick AE. 1980. Sympathetic influences on coronary perfusion and evolving concepts of driving pressure, resistance, and transmural flow regulation. Anesthesiology 52:1-5.

Klocke FJ, Weinstein IR, Klocke JF, Romanowski RR, Anbar RD, Wallmeyer KW, Echt MP, Kraus DR, and Mates RE. 1981. Curvilinearity of the diastolic pressure-flow relationship in autoregulating and maximally vasodilated coronary beds; effects on estimates of zero-flow pressure and differences between zero-flow and intracavitary diastolic pressures. Role of capacitive effects in the determination of zero-flow pressure from long diastoles. Basic Res Cardiol 76:556-558.

Landoni G, Greco T, Biondi-Zoccai G, Nigro Neto C, Febres D, Pintaudi M, Pasin L, Cabrini L, Finco G, and Zangrillo A. 2013. Anaesthetic drugs and survival: a Bayesian network meta-analysis of randomized trials in cardiac surgery. Br J Anaesth 111:886-896. 10.1093/bja/aet231

Lang XE, Wang X, Zhang KR, Lv JY, Jin JH, and Li QS. 2013. Isoflurane preconditioning confers cardioprotection by activation of ALDH2. PLoS One 8:e52469. 10.1371/journal.pone.0052469

Leung JM, Goehner P, O'Kelly BF, Hollenberg M, Pineda N, Cason BA, and Mangano DT. 1991. Isoflurane anesthesia and myocardial ischemia: comparative risk versus sufentanil anesthesia in patients undergoing coronary artery bypass graft surgery. The SPI (Study of Perioperative Ischemia) Research Group. Anesthesiology 74:838-847.

Maas JJ, de Wilde RB, Aarts LP, Pinsky MR, and Jansen JR. 2012. Determination of vascular waterfall phenomenon by bedside measurement of mean systemic filling pressure and critical closing pressure in the intensive care unit. Anesthesia and analgesia 114:803.

Nanto S, Masuyama T, Takano Y, Hori M, and Nagata S. 2001. Determination of coronary zero flow pressure by analysis of the baseline pressure-flow relationship in humans. Jpn Circ J 65:793-796.

Priebe HJ, and Foex P. 1987. Isoflurane causes regional myocardial dysfunction in dogs with critical coronary artery stenoses. Anesthesiology 66:293-300.

Pulley DD, Kirvassilis GV, Kelermenos N, Kater K, Barzilai B, Genton RE, Efstathiou C, and Lappas DG. 1991. Regional and global myocardial circulatory and metabolic effects of isoflurane and halothane in patients with steal-prone coronary anatomy. Anesthesiology 75:756-766.

Shimada K, Sakanoue Y, Kobayashi Y, Ehara S, Hirose M, Nakamura Y, Fukuda D, Yamagishi H, Yoshiyama $\mathrm{M}$, Takeuchi $\mathrm{K}$, and Yoshikawa J. 2003. Assessment of myocardial viability using coronary zero flow pressure after successful angioplasty in patients with acute anterior myocardial infarction. Heart 89:71-76.

Takami Y, and Ina H. 2001. A simple method to determine anastomotic quality of coronary artery bypass grafting in the operating room. Cardiovasc Surg 9:499-503.

Walpoth BH, Bosshard A, Genyk I, Kipfer B, Berdat PA, Hess OM, Althaus U, and Carrel TP. 1998. Transittime flow measurement for detection of early graft failure during myocardial revascularization. Ann Thorac Surg 66:1097-1100.

Yamamuro A, Akasaka T, Tamita K, Yamabe K, Katayama M, Takagi T, and Morioka S. 2002. Coronary flow velocity pattern immediately after percutaneous coronary intervention as a predictor of complications and in-hospital survival after acute myocardial infarction. Circulation 106:30513056. 


\section{Table $\mathbf{1}$ (on next page)}

Table1 
1 Table1

\begin{tabular}{|l|l|l|l|}
\hline & Control $(\mathrm{n}=10)$ & Isoflurane $(\mathrm{n}=10)$ & $\mathrm{p}$-value \\
\hline Age (years) & $70(58-79)$ & $71(51-81)$ & 0.44 \\
\hline Weight $(\mathrm{kg})$ & $80(60-92)$ & $75(60-103)$ & 0.68 \\
\hline Height $(\mathrm{cm})$ & $168(153-82)$ & $168(156-180)$ & 0.68 \\
\hline Gender (male/female) & $8 / 2$ & $9 / 1$ & 0.53 \\
\hline Body surface area (m $\left.{ }^{2}\right)$ & $1.89(1.57-2.12)$ & $1.89(1.59-2.09)$ & 0.97 \\
\hline Coronary artery disease & 3 vessel disease, $\mathrm{n}=7$ & 3 vessel disease, $\mathrm{n}=6$ & \\
\hline Grafts (n) & 2 vessel disease, $\mathrm{n}=3$ & 2 vessel disease, $\mathrm{n}=3$ & \\
\hline Aortic clamping time (minutes) & $78(61-92)$ & 1 vessel disease, $\mathrm{n}=1$ & \\
\hline Reperfusion time (minutes) & $44(32-65)$ & $4(2-5)$ & 0.68 \\
\hline
\end{tabular}




\title{
Table 2 (on next page)
}

\author{
Table2
}




\begin{tabular}{|c|c|c|c|c|c|c|}
\hline & Control & & & Isoflurane & & \\
\hline & $\mathrm{T}_{15}$ & $\mathrm{~T}_{30}$ & $\begin{array}{l}\text { Control } \\
\text { T15 vs } \\
\text { T30 (p- } \\
\text { value) }\end{array}$ & $\mathrm{T}_{15}$ & $\mathrm{~T}_{30}$ & $\begin{array}{l}\text { Isoflurane } \\
\text { T15 vs } \\
\text { T30 (p- } \\
\text { value) }\end{array}$ \\
\hline $\mathrm{CI}\left(1 \mathrm{~min}^{-1} \mathrm{~m}^{-2}\right)$ & $\begin{array}{ll}2.9 \quad(2.3- \\
3.6) & \end{array}$ & $\begin{array}{ll}2.7 & (2.1- \\
3.2) & \end{array}$ & 0.11 & $\begin{array}{ll}2.7 & (1.6- \\
5.7) & \end{array}$ & \begin{tabular}{|ll}
2.6 & $(1.9-$ \\
$5.8)$ &
\end{tabular} & 0.28 \\
\hline $\operatorname{HR}\left(\min ^{-1}\right)$ & $\begin{array}{l}89 \quad(53- \\
106)\end{array}$ & $90(56-106)$ & 0.65 & $\begin{array}{l}99 \quad(76- \\
112)\end{array}$ & \begin{tabular}{|ll}
88 & $(74-$ \\
$100)$ &
\end{tabular} & 0.15 \\
\hline MAP (mmHg) & $65(47-80)$ & $66(56-84)$ & 0.06 & $69(59-85)$ & $57(48-59)$ & 0.005 \\
\hline $\begin{array}{l}\text { MDAP } \\
(\mathrm{mmHg})\end{array}$ & $57(45-64)$ & $60(43-71)$ & 0.06 & $62(53-79)$ & $50(45-57)$ & 0.005 \\
\hline DDT (ms) & $\begin{array}{l}447 \quad(257- \\
1215)\end{array}$ & $\begin{array}{l}489 \quad(366- \\
1070)\end{array}$ & 0.60 & $\begin{array}{l}721 \quad(240- \\
919)\end{array}$ & $\begin{array}{l}567 \quad(339- \\
937)\end{array}$ & 0.33 \\
\hline CVP (mmHg) & $9(7-16)$ & $9(7-16)$ & 1.0 & $10(7-12)$ & $10(7-13)$ & 0.82 \\
\hline $\mathrm{CSP}(\mathrm{mmHg})$ & $14(8-18)$ & $13(7-18)$ & 0.39 & $10(5-20)$ & $10(6-19)$ & 0.44 \\
\hline $\begin{array}{l}\text { SVRI (dyn sec } \\
\mathrm{cm}^{-5} \mathrm{~m}^{2} \text { ) }\end{array}$ & $\begin{array}{l}1555 \\
(809- \\
2454)\end{array}$ & $\begin{array}{l}1716 \\
(1355- \\
2193)\end{array}$ & 0.31 & $\begin{array}{l}1730 \\
(850- \\
2969)\end{array}$ & $\begin{array}{l}1364(699- \\
1965)\end{array}$ & 0.04 \\
\hline GEDI $\left(\mathrm{ml} \mathrm{m}^{-2}\right)$ & $\begin{array}{l}642 \quad(541- \\
895)\end{array}$ & $\begin{array}{ll}652 & (594- \\
883) & \end{array}$ & 0.78 & $\begin{array}{l}642 \quad(457- \\
834)\end{array}$ & $\begin{array}{l}617 \quad(479- \\
802)\end{array}$ & 0.92 \\
\hline EVLWI $\left(\mathrm{ml} \mathrm{m}^{-}\right.$ & $6.8 \quad(5.7-$ & $\begin{array}{ll}6.3 \quad(5.0- \\
\end{array}$ & 0.62 & $7.4 \quad(4.0-$ & $\begin{array}{ll}7.0 \quad(4.3- \\
\end{array}$ & 0.16 \\
\hline
\end{tabular}




\begin{tabular}{|c|c|c|c|c|c|c|}
\hline$\left.{ }^{2}\right)$ & $10.0)$ & $8.7)$ & & 10.7) & 10.0) & \\
\hline $\begin{array}{l}\text { LVEDP } \\
\text { (mmHg) }\end{array}$ & $16(8-33)$ & $15(8-30)$ & 0.09 & $11(8-37)$ & $13(9-22)$ & 0.80 \\
\hline \begin{tabular}{|l} 
SVV (\%) \\
\end{tabular} & $11(6-17)$ & $12(5-18)$ & 0.64 & $12(5-19)$ & $14(8-16)$ & 0.43 \\
\hline $\begin{array}{l}\mathrm{dp} / \mathrm{dt}_{\max } \\
\left(\mathrm{mmHg} \mathrm{s}^{-1}\right)\end{array}$ & $\begin{array}{l}766 \quad 507- \\
1063)\end{array}$ & $\begin{array}{l}763 \quad(500- \\
887)\end{array}$ & 0.65 & $\begin{array}{l}748 \quad(510- \\
1350)\end{array}$ & $\begin{array}{l}651 \quad(340- \\
1143)\end{array}$ & 0.02 \\
\hline CFI $\left(\min ^{-1}\right)$ & $\begin{array}{l}4.2 \quad(3.5- \\
5.0)\end{array}$ & $\begin{array}{ll}3.7 & (2.8- \\
5.0) & \end{array}$ & 0.05 & $\begin{array}{l}4.6 \quad(2.5- \\
8.1)\end{array}$ & $\begin{array}{l}3.9 \quad(3.1- \\
7.4)\end{array}$ & 0.16 \\
\hline COP (mmHg) & $39(23-48)$ & $42(28-44)$ & 0.25 & $35(26-59)$ & $34(27-42)$ & 0.11 \\
\hline $\begin{array}{l}\text { FLOW } \\
(\mathrm{ml} / \mathrm{min})\end{array}$ & $26(10-38)$ & $22(9-53)$ & 0.72 & $29(7-68)$ & $23(11-50)$ & 0.24 \\
\hline Slope (B1) & $\begin{array}{l}1.36 \\
(0.48- \\
2.71)\end{array}$ & $\begin{array}{l}1.29(0.46- \\
2.10)\end{array}$ & 0.49 & $\begin{array}{l}0.94 \\
(0.50- \\
4.82)\end{array}$ & $\begin{array}{l}2.03(0.56- \\
4.41)\end{array}$ & 0.02 \\
\hline $\begin{array}{l}\text { CVR from } \\
\text { Slope 1/B1 }\end{array}$ & $\begin{array}{l}0.74 \\
(0.37- \\
2.10)\end{array}$ & $\begin{array}{l}0.78(0.48- \\
2.17)\end{array}$ & 0.49 & $\begin{array}{l}1.06 \\
(0.21- \\
2.02)\end{array}$ & $\begin{array}{l}0.51(0.23- \\
1.79)\end{array}$ & 0.007 \\
\hline CVR from CSP & $\begin{array}{l}1.73 \\
(1.21- \\
3.92)\end{array}$ & $\begin{array}{l}1.83(0.94- \\
5.51)\end{array}$ & 0.69 & $\begin{array}{l}1.80 \\
(0.78- \\
8.83)\end{array}$ & $\begin{array}{l}1.35(0.81- \\
3.35)\end{array}$ & 0.30 \\
\hline $\begin{array}{ll}\text { CVR } & \text { from } \\
\text { LVEDP } & \end{array}$ & $\begin{array}{l}1.66 \\
(0.81-\end{array}$ & $\begin{array}{l}1.86(0.61- \\
5.64)\end{array}$ & 0.49 & $\begin{array}{l}1.68 \\
(0.79-\end{array}$ & $\begin{array}{l}1.77(0.73- \\
3.13)\end{array}$ & 0.06 \\
\hline
\end{tabular}




\begin{tabular}{|c|c|c|c|c|c|c|}
\hline & $4.05)$ & & & 5.38) & & \\
\hline $\begin{array}{l}\text { CVR from } \\
\text { COP }\end{array}$ & $\begin{array}{l}\text { O.74 } \\
(0.37- \\
2.07)\end{array}$ & $\begin{array}{l}0.78(0.46- \\
2.13)\end{array}$ & 0.44 & $\begin{array}{l}1.06 \\
(0.21- \\
2.02)\end{array}$ & $\begin{array}{l}0.51(0.23- \\
1.79)\end{array}$ & 0.006 \\
\hline
\end{tabular}

2 


\section{Table $\mathbf{3}$ (on next page)}

Table3 
1 Table3

\begin{tabular}{|c|c|c|}
\hline & $\begin{array}{l}\text { Control vs Isoflurane } \\
\text { T15 (p-value) }\end{array}$ & $\begin{array}{l}\text { Control vs Isoflurane } \\
\text { T30 (p-value) }\end{array}$ \\
\hline CI (1 min-1 m-2) & 0.96 & 0.90 \\
\hline HR (min-1) & 0.90 & 0.85 \\
\hline MAP (mmHg) & 0.06 & 0.009 \\
\hline MDAP (mmHg) & 0.06 & 0.01 \\
\hline DDT (ms) & 0.56 & 0.90 \\
\hline CVP (mmHg) & 0.96 & 0.83 \\
\hline CSP (mmHg) & 0.16 & 0.11 \\
\hline SVRI (dyn sec cm-5 m2) & 0.51 & 0.05 \\
\hline GEDI (ml m-2) & 0.69 & 0.27 \\
\hline EVLWI (ml m-2) & 0.31 & 0.41 \\
\hline LVEDP (mmHg) & 0.34 & 0.47 \\
\hline SVV (\%) & 0.96 & 0.57 \\
\hline $\mathrm{dp} / \mathrm{dtmax}(\mathrm{mmHg} \mathrm{s}-1)$ & 0.96 & 0.57 \\
\hline CFI (min-1) & 0.56 & 0.76 \\
\hline $\mathrm{COP}(\mathrm{mmHg})$ & 0.87 & 0.11 \\
\hline FLOW (ml/min) & 0.38 & 0.79 \\
\hline Slope (B1) & 0.79 & 0.05 \\
\hline CVR from Slope 1/B1 & 0.87 & 0.14 \\
\hline CVR from CSP & 0.83 & 0.28 \\
\hline CVR from LVEDP & 0.85 & 0.39 \\
\hline
\end{tabular}


2 


\section{Table 4(on next page)}

Table4 


\section{Table4}

\begin{tabular}{|c|c|c|c|c|c|c|}
\hline & \multicolumn{2}{|c|}{ Control } & \multirow[b]{2}{*}{$\begin{array}{c}\text { Control } \\
\mathrm{T}_{15} \text { vs } \mathrm{T}_{30}\end{array}$} & \multicolumn{2}{|c|}{ Isoflurane } & \multirow[b]{2}{*}{$\begin{array}{l}\text { Isoflurane } \\
\mathrm{T}_{15} \text { vs } \mathrm{T}_{30}\end{array}$} \\
\hline & $\mathrm{T}_{15}$ & $\mathrm{~T}_{30}$ & & $\mathrm{~T}_{15}$ & $\mathrm{~T}_{30}$ & \\
\hline $\mathrm{Hb}_{\mathrm{art}}(\mathrm{g} / \mathrm{dl})$ & $9.1(7.5-10.0)$ & $9.0(7.8-10.9)$ & 0.51 & $9.2(8.1-10.3)$ & $9.2(7.6-11.6)$ & 0.91 \\
\hline $\mathrm{S}_{\mathrm{a}} \mathrm{O}_{2}(\%)$ & $\begin{array}{c}99(94.1- \\
99.6)\end{array}$ & $99(93.7-99.9)$ & 1.0 & 99 (98.7-99.7) & 99 (97.2-99.7) & 0.31 \\
\hline $\mathrm{P}_{\mathrm{a}} \mathrm{O}_{2}(\mathrm{mmHg})$ & $163(71-298)$ & $153(75-364)$ & 0.43 & $200(124-293)$ & $213(141-277)$ & 0.28 \\
\hline $\mathrm{P}_{\mathrm{a}} \mathrm{CO}_{2}(\mathrm{mmHg})$ & $46(38-54)$ & $48(39.7-51.7)$ & 0.08 & $43(35-55)$ & $44(34-50)$ & 0.82 \\
\hline $\mathrm{pH}_{\text {art. }}$ & $\begin{array}{c}7.35(7.24- \\
7.41) \\
\end{array}$ & $\begin{array}{c}7.35(7.22- \\
7.38) \\
\end{array}$ & 0.08 & $\begin{array}{c}7.35(7.24- \\
7.44) \\
\end{array}$ & $7.34(7.28-7.45)$ & 1.0 \\
\hline $\mathrm{BE}_{\text {art. }}(\mathrm{mmol} / \mathrm{l})$ & $-0.4(-7.6-1.3)$ & $-1.2(-7.2-1.1)$ & 0.55 & $-1.4(-4.4-1.2)$ & $-2.4(-3.6-0.1)$ & 0.31 \\
\hline $\mathrm{SBIC}_{\text {art. }}(\mathrm{mmol} / \mathrm{l})$ & $\begin{array}{c}24.1(18.2- \\
25.5)\end{array}$ & $\begin{array}{c}23.5(18.5- \\
25.5)\end{array}$ & 0.58 & $\begin{array}{c}22.7(20.7- \\
24.2)\end{array}$ & $22.4(21.4-24.6)$ & 0.43 \\
\hline $\mathrm{S}_{\mathrm{cs}} \mathrm{O}_{2}(\%)$ & $49(23.5-82.9)$ & $46(39.3-74.9)$ & 0.49 & $46(29.7-74.5)$ & $56(33.1-80.3)$ & 0.05 \\
\hline $\mathrm{P}_{\mathrm{cs}} \mathrm{O}_{2}(\mathrm{mmHg})$ & $26(19-51)$ & $27(24-43)$ & 0.70 & $27(19-44)$ & $33(22-49)$ & 0.006 \\
\hline $\mathrm{P}_{\mathrm{cs}} \mathrm{CO}_{2}(\mathrm{mmHg})$ & $56(38-64)$ & $58(48-62)$ & 0.06 & $54(38-66)$ & $55(40-64)$ & 1.0 \\
\hline $\mathrm{pH}_{\mathrm{cs}}$ & $\begin{array}{c}7.30(7.14- \\
7.35) \\
\end{array}$ & $\begin{array}{c}7.30(7.17- \\
7.32) \\
\end{array}$ & 0.13 & $\begin{array}{c}7.30(7.19- \\
7.42) \\
\end{array}$ & $7.28(7.23-7.40)$ & 0.30 \\
\hline $\mathrm{BE}_{\mathrm{cs}}(\mathrm{mmol} / \mathrm{l})$ & $0.3(-7.9-2.0)$ & $-0.1(-6.8-1.9)$ & 0.91 & $-1.4(-3.9-0.7)$ & $-2.2(-3.4-0.2)$ & 0.02 \\
\hline $\mathrm{SBIC}_{\mathrm{cs}}(\mathrm{mmol} / \mathrm{l})$ & $\begin{array}{c}23.9(17.0- \\
25.3)\end{array}$ & $\begin{array}{c}23.7(18.1- \\
25.2)\end{array}$ & 0.84 & $\begin{array}{c}22.6(20.8- \\
24.3 \\
\end{array}$ & $21.9(21.3-24.2)$ & 0.03 \\
\hline Lactate $_{\mathrm{cs}}(\mathrm{mmol} / \mathrm{l})$ & $1.0(0.6-5.8)$ & $1.0(0.5-5.3)$ & 0.16 & $1.8(1.0-3.0)$ & $2.0(0.8-2.7)$ & 0.39 \\
\hline $\begin{array}{l}\text { Isoflurane }_{\mathrm{cs}} \\
(\mu \mathrm{g} / \mathrm{dl})\end{array}$ & 0 & 0 & & 0 & $1.4(0.8-2.3)$ & \\
\hline
\end{tabular}

2 


\section{Table 5(on next page)}

Table5 


\section{Table5}

\begin{tabular}{|c|c|c|}
\hline & $\begin{array}{l}\text { Control vs Isoflurane } \\
\mathrm{T}_{15} \text { (p-value) }\end{array}$ & $\begin{array}{l}\text { Control vs Isoflurane } \\
\mathrm{T}_{30}(\mathrm{p} \text {-value })\end{array}$ \\
\hline $\mathrm{Hb}_{\text {art }}(\mathrm{g} / \mathrm{dl})$ & 0.43 & 0.57 \\
\hline $\mathrm{S}_{\mathrm{a}} \mathrm{O}_{2}(\%)$ & 0.17 & 0.32 \\
\hline $\mathrm{P}_{\mathrm{a}} \mathrm{O}_{2}(\mathrm{mmHg})$ & 0.32 & 0.08 \\
\hline $\mathrm{P}_{\mathrm{a}} \mathrm{CO}_{2}(\mathrm{mmHg})$ & 0.39 & 0.12 \\
\hline $\mathrm{pH}_{\text {art. }}$ & 0.35 & 0.68 \\
\hline $\mathrm{BE}_{\text {art. }}(\mathrm{mmol} / \mathrm{l})$ & 0.22 & 0.25 \\
\hline $\mathrm{SBIC}_{\text {art. }}(\mathrm{mmol} / \mathrm{l})$ & 0.19 & 0.25 \\
\hline $\mathrm{S}_{\mathrm{cs}} \mathrm{O}_{2}(\%)$ & 0.85 & 0.17 \\
\hline $\mathrm{P}_{\mathrm{cs}} \mathrm{O}_{2}(\mathrm{mmHg})$ & 0.58 & 0.17 \\
\hline $\mathrm{P}_{\mathrm{cs}} \mathrm{CO}_{2}(\mathrm{mmHg})$ & 0.80 & 0.35 \\
\hline $\mathrm{pH}_{\mathrm{cs}}$ & 0.79 & 0.85 \\
\hline $\mathrm{BE}_{\mathrm{cs}}(\mathrm{mmol} / \mathrm{l})$ & 0.53 & 0.17 \\
\hline $\mathrm{SBIC}_{\mathrm{cs}}(\mathrm{mmol} / \mathrm{l})$ & 0.63 & 0.16 \\
\hline Lactate $_{\mathrm{cs}}(\mathrm{mmol} / \mathrm{l})$ & 0.06 & 0.03 \\
\hline Isoflurane $_{\mathrm{cs}}(\mu \mathrm{g} / \mathrm{dl})$ & & \\
\hline
\end{tabular}

2 